\title{
The United States and the making of an Arctic nation
}

\author{
Annika E. Nilsson \\ Stockholm Environment Institute, Box 24218, 10451 Stockholm, Sweden \\ (annika.nilsson@sei.org)
}

Received October 2017; first published online 23 May 2018

ABSTRACT. The United States has sometimes been called a reluctant Arctic actor, but during its chairmanship of the Arctic Council (2015-2017) the US engaged as an active proponent of Arctic cooperation, using the region as a showcase for strong global climate policy. This paper places US Arctic policy development during the Obama presidency within a longer time perspective, with a focus on how US interests towards the region have been formulated in policies and policy statements. The paper uses frame analysis to identify overarching discourses and discusses the extent to which certain themes and political logics recur or shift over time. It highlights economic development and national competitiveness as a prominent recurring frame, but also that the policy discourse has moved from nation-building and military security towards a broader security perspective, with attention to energy supply for the US, and more recently also to the implications of climate change. Over time, there is a clear shift from reluctance towards Arctic regional cooperation to embracing it. Moreover, it highlights how different stands in relation to climate change have affected Arctic cooperation in the past and may do so again in the future.

\section{Introduction}

The United States has sometimes been called a reluctant Arctic actor (c.f. Østhagen, 2011), but during the country's chairmanship of the Arctic Council (2015-2017) the level of visible activity increased considerably. Examples include leadership towards an agreement of scientific cooperation and a high-profile meeting on climate change in Alaska, setting the stage for the United States to assume a new role in Arctic affairs with a focus on climate change. In 2017 the tables turned as Donald Trump took over the US presidency, with a political direction based on climate skepticism, strong support for the fossil fuel industry, and a focus on national interests rather than international cooperation. Amidst questions of what the shift in policy would mean for the Arctic, the US Chair of the Arctic Council's Senior Arctic Officials, David Balton, said that, based on previous experience, there would be more continuity than change in US Arctic policy (Balton, 2017; Storholm, 2017).

While US policy towards fossil-fuel extraction in the Arctic has clearly shifted and the Trump administration has a more skeptical attitude towards international cooperation in general and towards international climate change cooperation in particular, US commitment to Arctic regional cooperation in the Arctic Council was reasserted by Secretary of State Rex Tillerson at the Arctic Council ministerial meeting in Fairbanks, Alaska in May 2017. The question thus remains whether US Arctic policy in a longer time perspective has been characterised by continuity or major shifts. To address this question, this paper uses frame analysis to identify overarching logics in US policy towards the Arctic as a circumpolar region.

The analysis is set against a background of increasing interest in Arctic politics, with a growing number of
Washington think tanks active in the debate (Martinson, 2016a) and issuing reports (e.g. Cohen, 2010; Conley, 2013). However, although in recent years there has been increasing academic attention towards new Arctic actors, such as China and other Asian countries, only a few authors have focused on US Arctic policy. Arnaudo (2013) provides a relatively recent analysis from within the government, also suggesting continuity in US Arctic policy, while Nord (2007) a while back compared US and Canadian efforts to develop a comprehensive international northern policy, and May et al. (2005) studied national policy coherence in relation to Arctic issues. Lacking is an analysis that includes Obama's push for attention to the Arctic before and during the US Arctic Council chairmanship, and how this push relates to the long-term development of US foreign policy in relation to the Arctic. This article aims to fill this gap by placing this push into an analysis of how the US Arctic interests have been framed and reframed over time.

\section{Frame theory as a tool for analysis}

The slogan for the US chairmanship of the Arctic Council (2015-2017) was "One Arctic - Shared Responsibility" but one can also argue that there are many Arctics, depending on who is talking (Cornell, Downing, \& Clark, 2016; Young \& Einarsson, 2004). For some, the Arctic is mainly an arena for military security concerns or a source of valuable natural resources, and yet others would primarily highlight its threatened environment or the Arctic as home. Frames can be described as a cognitive mechanism that people use for making sense of new information in relation to an earlier understanding of the larger context. In political discourse, frames can set the boundaries for discussions, and the process of framing by 
Table 1. Description of frames, adapted from Nisbet, 2009 (Buurman \& Christensen, 2017).

\begin{tabular}{|c|c|}
\hline Frame & Description \\
\hline $\begin{array}{l}\text { Social development/ human } \\
\text { well-being }\end{array}$ & $\begin{array}{l}\text { A means of improving quality of life, solving problems; measures towards } \\
\text { reducing imminent or future risks and human security threats; strengthening } \\
\text { nature-culture connectivity. }\end{array}$ \\
\hline $\begin{array}{l}\text { Economic development and } \\
\text { competitiveness }\end{array}$ & $\begin{array}{l}\text { Economic investment or growth; market benefit or risk, or a point of local, } \\
\text { national or global competitiveness; labour and workforce dimensions. }\end{array}$ \\
\hline Morality and ethics & $\begin{array}{l}\text { A matter of right or wrong; environmental and/or virtue ethics; } \\
\text { decision-making for the greater good; respect or disrespect for limits, } \\
\text { thresholds, or moral, ethnic boundaries and capabilities. }\end{array}$ \\
\hline Science and technology & $\begin{array}{l}\text { Scientific activities and cooperation; knowledge production and } \\
\text { scientific-technical infrastructure; a matter of expert understanding or } \\
\text { consensus; a debate over what is known versus unknown or certain versus } \\
\text { uncertain. }\end{array}$ \\
\hline $\begin{array}{l}\text { Environment/ environmental } \\
\text { change }\end{array}$ & $\begin{array}{l}\text { Environment-related concerns; spatial and temporal projections of near, } \\
\text { distant or future risks. }\end{array}$ \\
\hline Governing and politics & $\begin{array}{l}\text { Arctic-relevant legislations (national and international), regulations and } \\
\text { decision-making; call for governance through policy interventions or } \\
\text { imposition of codes of conduct. }\end{array}$ \\
\hline Conflict and strategy & $\begin{array}{l}\text { A supremacy game, such as who is winning or losing, or a battle or clash of } \\
\text { groups (such as nation-states or communities and states); often concerning } \\
\text { resource or military security, or symbolic or actual displays of power. }\end{array}$ \\
\hline
\end{tabular}

naming, selecting and storytelling plays a role in shaping policies and policy implementation (for a discussion of frames and framing in policy studies, see van Hulst \& Yanow, 2016). Frame theory has become an important tool for analysing political and media discourses about climate change (Christensen, 2013; Nisbet, 2009) and has recently been applied to analyses of how Arctic politics is framed in media and state policies (e.g. Christensen, 2013; Pincus \& Ali, 2016; Wilson Rowe, 2013). Frames that become embedded in written policies provide a window into the dominating political logic at the time these policies were articulated. Especially relevant in looking at policy development is a focus on the process by which frames are created and become established (Björnehed \& Erikson, 2018; van Hulst \& Yanow, 2016) and on efforts to reframe an issue in such a way that a new political logic emerges, for example by an alignment of previously diverging political priorities. Frames that become established can be the result of various policy-shaping processes (for example, agenda setting, advocacy coalitions, power through power elites or community organising, etc. (see Stachowiak, 2013)). The focus here is not on these processes as such but on their result in terms of the frames that become embedded in policies.

The Arctic is in the political limelight today because of climate change, and this article takes its analytical starting point in a categorisation of frames initially developed by Nisbet (2009) in a study of why frames matter in climate communication. The analysis builds on identifying presence or non-presence of seven overarching frames in the empirical material, each of which is generic enough to be relevant in different historical contexts and thus useful to look for shifts in emphasis over time. Slightly modified from the original, these overarching frames are (1) social development/human well-being, (2) economic develop- ment and competitiveness, (3) morality and ethics, (4) science and technology, (5) environment/environmental change, (6) governing and politics, and (7) conflict and strategy (Buurman \& Christensen, 2017). Each of these frames has its own political and policy relevance, depending on the specific policy concern in focus, and they are all potentially relevant as part of an Arctic policy.

The analysis in this paper uses the seven overall frames described in detail in Table 1 for highlighting the dominating logic of the United States as an Arctic actor and how US perspectives have changed (or not changed) over time. The empirical foundations for the analysis are policy documents and statements, along with a review of previously published work on US Arctic activities.

The body of the paper is organised chronologically, starting with providing some historical background as context and then focusing on a time frame that stretches from the discovery of oil in Alaska in 1968 to the finalisation of the US chairmanship of the Arctic Council in May 2017, with some added comment on developments during the rest of 2017.

\section{Historical context}

The United States acquired its Arctic territory from the Russian Empire in 1867 with the Alaska purchase. US Secretary of State William H. Seward was keen on expanding the boundaries of the new nation as part of his grand scheme of turning the United States into a global power, with a vision of the United States as a main character in this world of global communication networks, free trade and financial integration (Emmerson, 2010, p. 75). A speech in Sitka in 1869 illustrates how he saw Alaska as vastly 
rich in resources at a time of declining global supplies and that the expansion of US military protection and civil government to Alaska would be a guarantee for free trade (Seward, 1869). Seward also wanted to acquire Greenland and Iceland as US territory and commissioned mapping of their resources, which resulted in positive reports about their potential for geological exploration, cultivation of the sea, and Iceland as a future strategic communication hub for telegraph cables (Emmerson, 2010, pp. 92-93, 123), but nothing became of these ideas and at the time Greenland and Iceland remained within the Danish realm.

Integration of Alaska into the United States took off when Alaska became a magnet for people moving north to look for mineral riches, including the Klondyke gold rush in the 1880s, the discovery of the Nome gold fields in 1898 and a gold rush centred on Fairbanks a few years later. New settlements were established around communication hubs and mining camps, and Alaska's population doubled from around 33,426 individuals in 1880 to 63,500 in 1900 (Barnett, 2013, p. 52). Along the coast, a small-scale fishery industry was starting to emerge, which would later develop into a major commercial activity. Following on the economic opportunities, new infrastructure was being developed, including regular steamer traffic, telegraph stations, efforts at mapping both seaways and inland, and US government surveys of mineral resources.

With control of resources and trade as prominent political drivers, the most important frame when the United States entered Arctic politics with the purchase of Alaska was that of economic development and competitiveness. The frame of governing and politics appears in parallel in the nation-building ambitions and the expansion of US government structures to the Arctic to facilitate exploitation of the region's riches.

The outbreak of World War II brought a shift in focus, in which Alaska's strategic location near the Pacific theatre of war created the setting for major military buildup, including the construction of the Alaskan Highway to connect Alaska to the rest of the United States. With incoming military personnel and growth in economy supporting the military activities, the population quickly grew, and exceeded 100,000 by 1941 . More importantly, the United States interests in the Arctic expanded far beyond national borders. The Soviet Union had gone from being considered a US ally to becoming its major foe and a transpolar path was the shortest route for a potential nuclear attack. With the prospect of Soviet planes coming from the north, the United States built a vast system for early warning with radar stations across the North American Arctic, with not only Alaska but also Canada and Greenland incorporated into US militarised space (Barnett, 2013, pp. 100-101). Moreover, there were major investments in research to better understand the conditions that would face any military operation in the polar environment (Doel, 2003; Emmerson, 2010, pp. 128-129).

Greenland became part of US military operations during the war but was even more in focus during the early years of the Cold War, when the American military essentially colonised Greenland and made Arctic geophysical research "subject to military direction, culture, and rules" (Heymann, Knudsen, Lolck, Nielsen, \& Ries, 2017). New installations included the Thule Station in northern Greenland and the construction of Camp Century, a city under the ice that operated from 1960 to 1966. The Arctic Ocean also became a high priority with the development of submarines that could navigate under the ice, and a key event was when the USS Nautilus travelled across the Arctic Ocean directly across the North Pole in 1962 (Emmerson, 2010, p. 132).

During WWII and in the Cold War period, a conflict and strategy frame clearly dominated US discussions about the Arctic, but another frame was on the rise: science and technology. As has recently become apparent from previously classified documents, these two frames were not in contrast to each other but worked in close tandem (Heymann et al., 2017). The US efforts were also fuelled by the fact that the Soviet Union was ahead in Arctic knowledge and capabilities. The military investment in the earth sciences set the stage for what later became known as global change science. At the time, interests in the environment were mainly related to military and strategic concerns, as it was imperative to have the capacity to operate in the extreme polar environments and to better understand the unexplored Arctic Ocean. However, the actual activities - such as basic research about the ocean environment - carried the seeds of the environment/environmental change frame that is more prominent in today's discussions about the Arctic. While the 1960s featured a push in Congress for more Arctic research and preparation for an initial broad statement of US Arctic policy, it was not acted on (Hickok, Weller, Davis, Alexander, \& Elsner, 1983, p. 6). It thus appears that the circumpolar north was not of enough interest in its own right to warrant any lasting region-specific initiatives. This started to change with the discovery of a large oil reserve at Prudhoe Bay in 1968.

\section{Petroleum development and an emerging indigenous movement (1968-1987)}

Interest in US Arctic petroleum resources had already appeared in the early 1900 s, but commercially the extraction of oil in the remote Arctic was not viable until the Prudhoe discovery and the potential for connecting to the oil market in the lower 48 states. Getting the oil out of the Arctic was a major issue and a trial voyage with the ice-breaking tanker SS Manhattan through the Northwest Passage north of Canada contributed to a soured relationship between the United States and Canada regarding Arctic policy, as the United States considers these waters to be an international strait whereas Canada considers the Northwest Passage to be internal waters (Friedheim, 1986). In 1969, the oil companies decided that a pipeline from Prudhoe Bay to Valdez in southern Alaska was the best option. The pipeline was controversial and the plans were challenged 
in court based on the potential environmental impacts, but the 1973 OPEC oil embargo and severe shortages of gasoline across the United States paved the way for a presidential authorisation to go ahead.

A major issue in planning for the pipeline was that some land over which it was to be built was claimed by native groups, which set in motion a series of negotiations that eventually led to the Alaska Native Claims Settlement Act in 1971 (Ervin, 1976). It was the largest native claims settlement act in US history and established native-owned corporations that would function under US corporate law (Barnett, 2013, p. 144), some of which have since become major businesses. The new focus on oil transformed Alaska's economy into one that is heavily dependent on income from the petroleum industry, with ups and downs following the global market (Cole \& Cravez, 2004).

Although the Inuit of the US Arctic had dealt with outsiders for over a century, the oil development of the 1970 s created a setting in which they were able to assert their own rights as indigenous peoples in a way that they had not done earlier. Because states and commercial actors wanted access to native lands and because those who lived there had concerns about the impacts of new industrial activities on the environment and traditional livelihoods, there was an increasing interest among Inuit to organise politically. Inupiat leader Eben Hobson used the situation as a base for articulating Inuit policy on sustainable development and environment protection in what became the Inuit Circumpolar Conference (ICC) at an inaugural meeting in 1977 (for a detailed account of the development of an Inuit polity, see Shadian, 2014). The ICC was later renamed the Inuit Circumpolar Council. By connecting discussions across the North American Arctic and Greenland (and to a more limited extent Chukotka), the ICC became a strong actor in shaping circumpolar Arctic policy.

The developments in the early 1970s made a mark on US policy in relation to the Arctic as expressed in the National Security Decision Memorandum 144 issued in December 1971. This memorandum spelled out that "the United States will support the sound and rational development of the Arctic, guided by the principle of minimizing any adverse effects to the environment; will promote mutually beneficial international cooperation in the Arctic; and will at the same time provide for the protection of essential security interests in the Arctic, including preservation of the principle of freedom of the seas and superjacent airspace" (Arnaudo, 2013; United States Arctic policy group, 1971). The memorandum was explicit that there was to be no public statement concerning US Arctic policy and the document remained classified until 1977.

The context for US Arctic political interests had thus started to shift towards a stronger focus on economic and energy security interests related to oil. Visible in the statement is also a shifting international political landscape. In addition to the emerging indigenous movement, it included increasing attention to environmental concern, where the concept of sustainable development was at the forefront of international political discussions. Moreover, the mid-1980s marked the end of long negotiations about the law of the sea, with the signing of the UN Convention of the Law of the Sea (UNCLOS) in 1982.

In this context, some US actors saw the lack of coordination of the country's Arctic activities as a problem. In 1981 the Alaska Division of the Association for the Advancement of Science published a report that called for a US Arctic science policy (later republished by the Alaska Council of Science and Technology as Hickok et al., 1983). It spelled out the need for a "renaissance in Arctic science...to guide national programs on resource development, international relations, defense, environmental protection, and human health." Such a policy was to address the delays in resource development, the unhealthy state of the US economy and the low status of the United States among the nations active in the Arctic as the three top issues in a list of nine. The report painted a picture of ad hoc and piecemeal US engagement in the Arctic, where the authors described US Arctic research as uncoordinated and unable to meet the increasing need to understand the Arctic environment. The authors specifically mentioned the new demands created by infrastructure investments such as the transAlaska pipeline, as well as the need to balance resource development and environmental protection and to attend to the social and health needs of Alaska's native peoples. In addition to the domestic issues, the report authors highlighted international dimensions in relation to future off-shore development and the need to negotiate unresolved issues about access to resources on the continental shelf. They also discussed climate change noting that "the Arctic and Antarctic are sensitive indicators of global climate change...that function as climatic controls that can cause abrupt (in geological time) reversals of climatic conditions." Another issue brought up in the report related to defense, with discussion about the immense Soviet capacity in the Arctic. Moreover, a section called "Human life and Occupancy" discussed the poor health among indigenous people along with the missed opportunities to use major infrastructure investment related to resource exploitation as a means to boost health care and to learn more about the health impacts of Arctic environments.

Unlike earlier failed attempts to develop a US Arctic Policy, the 1981 report was followed up and had legislative consequences. In 1983, the Reagan administration made a decision to review the report's recommendations, including consideration of possible increased international collaboration (United States, 1983). In 1984, Congress passed the Arctic Research and Policy Act, which served to "establish national policy, priorities, and goals and to provide a Federal program plan for basic and applied scientific research with respect to the Arctic, including natural resources and materials, physical, biological and health sciences, and social and behavioral sciences" (United States, 1984). It also created 
the US Arctic Research Commission and the Interagency Arctic Research Policy Committee, both of which are still active. The rationale is spelled out in the first section of the act, which states that "the Arctic, onshore and offshore, contains vital energy resources that can reduce the Nation's dependence on foreign oil and improve the national balance of payments...". Although it also lists 16 other reasons, energy security was clearly a major new impetus compared to previous defense-related concerns and more general scientific interest in Arctic environments. Given today's attention to climate change in the Arctic, it is interesting to note that the act mentions that "Arctic conditions directly affect global weather patterns and must be understood in order to promote better agricultural management throughout the United States" and that "industrial pollution not originating in the Arctic region... must be controlled through international cooperation and consultation." In general, however, the language of the Act is focused on national interests and national coordination in relation to research.

Oran Young's analysis in Foreign Affairs in 1985 provides a sense of the political context that promoted the Arctic Policy Research Act (Young, 1985). He noted that "quietly, and almost unbeknownst to the general public, the Arctic has emerged during the 1980s as a strategic arena of vital significance to both of the superpowers." A major development was in military technology, especially nuclear submarines with capacity to operate under the sea ice and the capacity to launch ballistic missiles with nuclear warheads, but also that the Arctic was rapidly industrialising and that some had questioned the security of industrial installations such as the Prudhoe Bay oil complex and the trans-Alaska pipeline. A third issue was the unresolved maritime border between Alaska and Canada and strained relations due to different views on the status of the Northwest Passage. Later, in 1988, after two years of negotiations, Canada and the United States signed an agreement on Arctic cooperation relating to navigation, development and security (Canada—United States, 1989).

To summarise the 1970s and 1980s, the development of the Prudhoe Bay oil field as a major supplier of cheap energy to the US market fundamentally changed US interests in the Arctic, making the Arctic relevant at the national level beyond interest related to military operations. The attention to cheap and secure access to energy from fossil fuels can be described as a new aspect of the strategy and conflict frame but more prominent was the frame economic development and competitiveness for the United States as a nation. The geopolitical context that helped to create such momentum was the OPEC oil embargo that had made obvious the vulnerability of the United States and many other countries to the economic interests of other global actors.

While these frames dominated the discourse and motivated investments, two competing frames are also visible in the discourse of the time. One relates to morality and ethics and more specifically to indigenous peoples' rights and health. Concerns related to environ- ment/environmental change, including climate change, also appeared in official writings about the Arctic and can thus be described as part of the mainstream debate. The focus on circumpolar cooperation discussed in the next section was mentioned in classified or low-profile documents but did not appear to have been part of the public discussion.

\section{Growing circumpolar cooperation (1987-1996)}

While internal US interests in the Arctic were shifting in the 1980s, the circumpolar political context was also gearing up for a sea of change in a process that has been described as the negotiated construction of a new international region (Keskitalo, 2004). By the time it had played its course - towards the mid-1990s - it represented a regime shift in circumpolar international relations from conflict to cooperation (Nilsson \& Koivurova, 2016), to which the United States had to relate. The shift had at least two origins. One was the increasing international attention to environmental issues and sustainable development. The other was a growing scientific interest in the dynamics of climate change in polar regions. To improve conditions for gathering data in the north, a small group of researchers started to discuss the possibility of creating a new international organisation for Arctic research, which after intense scientific and diplomatic discussions resulted in the creation of the International Arctic Science Committee (IASC) in 1990 (Archer \& Scrivener, 2000; Nilsson, 2007; Rogne, Rachold, Hacquebord, \& Corell, 2015). In addition to engagement by individual scientists, the United States was represented on IASC's Regional Board, which had the expressed purpose of making sure that IASC's activities were compatible with the interests of Arctic states (Archer \& Scrivener, 2000; Young, 1998).

While IASC was one step towards political cooperation in the Arctic, the explicitly political negotiations took place in the Rovaniemi process that began in 1989 and led to the signing of the Arctic Environmental Protection Strategy (AEPS) in 1991. It was a negotiation in which the United States kept a low profile and has been described as one of the most reluctant actors and a "real laggard" (Young, 1998, p. 106). Young attributed the US reluctance to the working of the US political systems, with complicated budget procedures and the need to clear specific language, rather than an explicit effort to block the initiative as such (Young, 1998, p. 196). While the United States did sign the agreement, its initial engagement in the activities of AEPS was limited.

The Rovaniemi process was a Finnish initiative but also linked to Canadian interests in creating an Arctic Council as a broader forum for circumpolar cooperation, an idea that did not sit well with the United States and led to sour relations between the United States and Canada (Friedheim, 1986). Specifically, the United States did not want to see a new international organisation emerge, especially not one with legal standing (Bloom, 
1999). According to Bloom (1999), the United States was especially concerned that the Arctic Council should not be able to hinder any independent actions by states.

Archer and Scrivener have described the initial US response as "hostile", where the United States argued that such a council would duplicate work in other international fora and could exclude non-Arctic states (Archer \& Scrivener, 2000, p. 613). The United States was also reluctant to include attention to climate issues in the AEPS and in general was not eager to define distinctly regional strategies for issues that were of global or national interest (Nord, 2007, p. 215). Tennberg's study of the creation of the Arctic Council mentions a lack of US Arctic identity and refers to how the US representatives in the negotiation often stressed the strategic importance of the Arctic (Tennberg, 1998, p. 87). A contemporary observer - the chair of the US-Canada Policy Forum attempting to negotiate a common ground between the United States and Canada - noted that the US position was most likely heavily influenced by the Department of Defense and thus by great-power national interests rather than the more domestically driven interests of Canada (Friedheim, 1986).

The military strategic frame was highly visible in the 1994 US Directive on policy towards the Arctic and Antarctic but was accompanied by other ways of framing US interests. The six objectives listed for the Arctic are "(1) meeting post-Cold War national security and defense needs, (2) protecting the Arctic environment and conserving its biological resources, (3) assuring that natural resource management and economic development in the region are environmentally sustainable, (4) strengthening institutions for cooperation among the eight Arctic nations, (5) involving the Arctic's indigenous peoples in decisions that affect them, and (6) enhancing scientific monitoring and research into local, regional and global environmental issues" (United States, 1994). The Directive specifically mentioned the shift from a Cold War situation as a reason to shift the emphasis of US Arctic policy more towards environmental protection, which in turn paved the way for a much more positive attitude towards circumpolar regional cooperation. The Directive specifically stated that "the Department of State and other agencies should seek better integration of the monitoring and assessment programs of all Arctic nations and pertinent international organizations" ... and that "[t]he United States should work with the other Arctic nations on measures to protect the marine environment from oil pollution and other adverse effects resulting from existing and planned land-based and offshore development activities and from potential increased use of the Arctic Ocean as a shipping corridor" (United States, 1994).

An issue on the rise was attention to indigenous communities and their role in decision making and policy development (Arnaudo, 2013). However, this also created a dilemma for the United States in the context of the negotiations for the Arctic Council, where the United States did not want strong indigenous representation or anything that could suggest acknowledging the special rights to indigenous peoples. For example, the United States opposed the term "peoples" with an "s". This dilemma also played out in discussions about the number and role of Permanent Participants in the Council. The Permanent Participants represent Arctic indigenous peoples and the negotiation resulted in a decision that they could not outnumber the states in the Council. According to Keskitalo, the opposition was partly in response to Canada's specific interest in raising the status of indigenous peoples in international cooperation and partly a reflection of a conflict between indigenous livelihoods related to hunting and environmental conservation voices within the United States (Keskitalo, 2004, p. 72).

In summary, the early 1990s represent a shift in US Arctic priorities. While the conflict and strategy frame was still present in the form of attention to military security, the environment/environmental change frame became much more central in the policy discourse. This was accompanied by a stronger focus on cooperation for peace and stability of the region and on research to better understand the Arctic environment, not for the sake of military needs but with the environment as such in focus, including the link to human well-being. The economic development and competitiveness frame that had been prominent earlier was more in the background, and circumscribed by the notion of environmental sustainability. The increased emphasis on the environment compared to economic interests in policy statements does not necessarily mean that environmental interests would trump economic ones in practical applications of policy. Nevertheless it does show that the US political discourse had changed enough that a single-minded focus on economic gain or security interests was no longer considered appropriate. Priorities that might in practice be a conflict were in the policy statements often described as equally important goals.

\section{Climate change and a renewed security agenda (1996-present)}

Climate change was not central in the early circumpolar political cooperation, but this changed at the very end of the 1990s with discussions about a regional Arctic climate impact assessment. The idea came partly from the US representative to IASC's Regional Board, Robert Corell, who saw the Arctic as a pilot for regional climate impact assessments to add to IPCC's more global focus. It was also pushed by indigenous peoples, ICC in particular, and as an initiative by one of the Arctic Council working groups (for a detailed discussion, see Nilsson, 2007). At the Barrow ministerial meeting at the end of the first US chairmanship of the Council, a decision was made to carry out what became known as the Arctic Climate Impact Assessment (ACIA).

According to its implementation plan, the ACIA was to include not only a scientific assessment but also a policy document based on the assessment. However, soon after the Barrow meeting, US politics featured a shift in 
presidency from Bill Clinton to George W. Bush. With it came a shift in climate policy towards a much more skeptical attitude to both climate science and international climate agreements, which had major implications for the ACIA policy process. Once the messages from the scientific assessment were becoming clear to the White House and to the US chief negotiator in the global climate negotiations, the policy process shifted from expert discussions to sharp political negotiations that mirrored the global discussions and disagreements. Tensions were further exacerbated by the fact that the impacts of climate change on the Arctic environment and on the traditional livelihoods of indigenous peoples were becoming visible, making it more difficult to brush off the scientific warnings that until then had been mainly based on scenarios of future change. These new results were not in line with US political priorities. In addition to the negotiations under the umbrella of the Arctic Council, the ACIA leadership, with Robert Corell as its chair, joined forces with ICC to push for discussions in Congress, including at a US Senate hearing (U.S. Senate Committee on Commerce, Science \& Transport, 2004). Despite the stark messages from ACIA, and due to strong reluctance from the US negotiator, the final text of the policy document was uncommitted to any action. At one point it was even uncertain whether there would be a policy statement and if the disagreement would threaten cooperation in the Arctic Council. Later, comments by a US representative to an Arctic Council working group suggested that the United States was very unhappy with the whole process (Nilsson, 2012).

Today, the US-led ACIA is often hailed as one of the most influential assessments carried out by the Arctic Council (Kankaanpää \& Young, 2012). However, the ACIA process illustrates a tension in US Arctic politics that was becoming increasingly acute: between concerns for the environmental and social impacts of economic development (now with a focus on climate change) and a wish to avoid any potential threat to the economic and security interests related to fossil fuels. Despite increasing climate skepticism in the US political discourse and a focus on the "uncertainty" of climate science in media reporting (Christensen, 2013), the US scientific community continued to engage in Arctic climate science. Eventually the realities of climate change and impact in the Arctic started to become apparent enough that they became difficult to ignore. The surprise record low sea-ice minimum in 2007, in particular, served as a reminder of the consequences of global climate change, not only in relation to the environment but also to national security interests.

In the climate discourse, the 2007 sea-ice minimum served as a meta-event and a starting point for increasing global attention to the region (Christensen, Nilsson, \& Wormbs, 2013). It coincided with increasing attention on the rights under UNCLOS to resources on the continental shelf, and efforts by several countries to provide scientific documentation of the seabed to back up claims about the outer limits of their extended continental shelf. In addition, the US Geological Survey in 2008 issued a report that claimed that $25 \%$ of hydrocarbon resources were to be found in the Arctic (Bird et al., 2008). The combination of events set off a wave of race-for-resources rhetoric, not least in media reporting (Pincus \& Ali, 2016), as well as discussion about the need to review governance in the region and specifically for the United States to pay more attention (e.g. Borgerson, 2008; Huebert, 2009). It suddenly became important for the United States and other Arctic countries to assert their special privileged role in the region. Being an "Arctic Nation" became immediately important even for countries that lacked clear Arctic identity.

In the United States, the situation set in motion a review of Arctic policy which resulted in president George W. Bush issuing a new Arctic policy at the very end of his presidency, on 9 January 2009 (National Security Presidential Directive-66 on Arctic Region Policy, 2009). As part of the background, it stated that " $[\mathrm{t}]$ he United States is an Arctic nation, with varied and compelling interests in that region." As rationale for articulating a new policy, it listed altered national policies on homeland security and defense; the effects of climate change and increasing human activity in the Arctic region; the establishment and ongoing work of the Arctic Council; and a growing awareness that the Arctic region is both fragile and rich in resources.

The policy goals did not shift much from the previous national policy statement. National security was still listed as a top priority, followed by environmental concerns, environmental sustainability of natural resource management and economic development, involving indigenous communities and enhancing scientific monitoring and research. In contrast to the US reluctance towards regional cooperation in the negotiations of the AEPS and the Arctic Council in 1990s, the policy highlighted a need to strengthen institutions for cooperation among the eight Arctic nations (United States, Canada, Denmark, Finland, Iceland, Norway, the Russian Federation and Sweden). However, although positive towards updating the structure of the Council, the United States did not want the Council to be transformed into a formal international organisation.

Another topic in the 2009 policy was the jurisdiction over marine areas, where the statement called for actions "to establish the outer limit of the continental shelf appertaining to the United States, in the Arctic and in other regions, to the fullest extent permitted under international law." It explicitly called for the Senate to promptly "act favorably on U.S. accession to the U.N. Convention on the Law of the Sea". The directive also referred to the unresolved boundary dispute with Canada in the Beaufort Sea and a US-Russia maritime boundary treaty from 1990 that had not yet entered into force. While these jurisdictional issues had been part of discussion for a long time, the declining sea ice and potential prospects for exploiting resources made it more urgent to resolve them as soon as possible.

A new term that appeared under the overall heading of national and homeland security was "domain awareness," 
referring to the protection of maritime commerce, critical infrastructure, and key resources. This term has become a prominent part of the US Arctic discourse (e.g. in the 2013 US Arctic Policy and the 2013 Department of Defense Arctic Strategy), and its usage illustrates how the changing Arctic environment, with its prospects of further sea-ice loss and increased economic activity, served as a wake-up call about the importance of the Arctic for US interests. Ongoing discussion about the need for US Arctic icebreaker capacity is another illustration of the perceived need to be present in the region, not only politically but also with physical capacities.

With Barack Obama's first term as president, the renewed interest in the Arctic became visible as a heightened international profile. A prominent turning point was when Hillary Clinton as Secretary of State attended the Arctic Council ministerial meeting in Nuuk, Greenland in May 2011. "We are going to raise the visibility of Arctic issues back in the United States so that we can begin to take the steps that are necessary for us," she said at a press conference on board a boat in the Nuuk fjord (Myers, 2011).

Two developments had made it urgent for the United States to become more engaged. One was Obama's political priority to take climate change seriously, despite difficulties of moving forward domestically. The second development related to the Arctic Council starting to take on a more active role in Arctic governance by signing a legally binding agreement on cooperation about search and rescue operations. It was starting to move from being a loosely defined high-level discussion club to becoming a body of practical significance. The ministerial declaration from Nuuk provided the foundation for that development to continue during the Swedish chairmanship (20112013), during which a permanent secretariat was established, and another binding agreement was signed - about preventing oil pollution and coordinating actions in case of oil spills in the Arctic. This was not a time for the United States to be left out of the discussion.

Five days before the Arctic Council's Kiruna ministerial meeting on 15 May 2013, the United States issued a new National Strategy for the Arctic Region (United States Federal Government, 2013). Echoing the tension between environmental and economic motives that started to become visible in the 1970 s, the preamble signed by Obama set a tone that tried to balance the language of economic opportunities and environmental protection: "The Arctic is one of our planet's last great frontiers. Our pioneering spirit is naturally drawn to this region, for the economic opportunities it presents and in recognition of the need to protect and conserve this unique, valuable, and changing environment." The strategy reaffirmed that the United States was an Arctic nation and was explicitly aimed to "position the United States to respond effectively to challenges and emerging opportunities arising from significant increases in Arctic activity due to the diminishment of sea ice and the emergence of a new Arctic environment."
The Strategy listed three priorities. The first related to advancing US national security interests when the Arctic Ocean opened up, including issues ranging from increasing the infrastructure capacity in ice-covered waters to defending rights of free passage according to the Law of the Sea. The second was about stewardship in terms of environmental protection and increasing knowledge about the region. The third was to strengthen international cooperation, including "working through bilateral relationships and multilateral bodies, including the Arctic Council." Following on Hillary Clinton's statement in Nuuk two years earlier, the strategy signalled a clear shift from reluctance towards circumpolar cooperation to embracing it.

Half a year later, the US Department of Defense issued its own Arctic Strategy, echoing the same strong focus on cooperation. The strategy highlighted the Arctic as being at "a strategic inflection point" that has created a "compelling opportunity...to work collaboratively with allies and partners to promote a balanced approach to improving human and environmental security in the region" (United States Department of Defense, 2013). The term security can mean many things, but this document signalled a broad definition that also emphasised human and civil security concerns, rather than exclusively military issues. The 2013 US Arctic Strategy was followed by an implementation plan aimed at facilitating collaboration between the many agencies, listing specific actions ranging from acceding to UNCLOS to ensuring the safe and responsible development of non-renewable energy resources. It also set out some guiding principles, including consulting and coordinating with Alaska Natives.

The ambitions were further stepped up at the beginning of 2015 when Obama created the Arctic Executive Steering Committee, which was tasked with supporting the White House in coordinating its Arctic efforts (The White House President Barack Obama, 2015a). The announcement of this new body stated that "[a]s a global leader, the United States has the responsibility to strengthen international cooperation to mitigate the greenhouse gas emissions driving climate change, understand more fully and manage more effectively the adverse effects of climate change, protect life and property, develop and manage resources responsibly, enhance the quality of life of Arctic inhabitants, and serve as stewards for valuable and vulnerable ecosystems."

The broad onus from the National Arctic Strategy and the creation of the Arctic Executive Steering Committee work carried over to the planning of priorities for the US chairmanship of the Arctic Council. While the US chairmanship programme featured some continuity from the Canadian chairmanship (2013-2015), particularly regarding a priority on improving economic and living conditions in Arctic communities, it also highlighted security, stewardship and addressing the impacts of climate change. The implication of climate change was particularly prominent at the high-profile GLACIER conference in Alaska in August 2015, where Barack Obama was the 
first sitting president to visit the US Arctic. This was not an Arctic Council meeting and was framed as a global rather than regional concern, with the timing and message aimed at pushing for a strong agreement at the Conference of the Parties of the UN Convention on Climate Change in Paris a few months later. In 2016, Obama's ambitious climate agenda was further supported by executive actions to protect areas of the northern Bering Sea where the United States resolved to "build a sustainable Arctic economy that relies on the highest safety and environmental standards, including adherence to national climate goals." He also used the 1953 Outer Continental Shelf Land Act, to "withdraw" all of the Chukchi Sea and the majority of the Beaufort Sea from future oil and gas leasing (Martinson, 2016b; The White House President Barack Obama, 2016). Moreover, Obama issued a joint statement with the Canadian Prime Minister Justin Trudeau committing to clean energy development, environmental protection and Arctic leadership (United States and Canada, 2016). Another high-level joint statement during the last year of the Obama presidency - with leaders of the Nordic countries - also featured commitment to cooperation in the Arctic and actions to mitigate climate change. Moreover, a shared US-Russia initiative of scientific collaboration in the Arctic was successfully concluded with science ministers from 24 countries gathered in Washington in September 2016, and was later signed by the Arctic Council's members as the Council's third legally binding agreement - this time to ensure facilitation of circumpolar scientific collaboration (Arctic Council, 2017a).

By early autumn 2016, the process of translating the new US Arctic policy into practice was thus well underway and if all had gone according to plan, the intensive work during the two years of US Arctic Council chairmanship would have been finalised with a much higher US profile in relation to international governance of the Arctic than had been apparent during previous administrations. However, in between came the presidential election and the inauguration of Donald Trump as Obama's successor. The Arctic has not been a highprofile issue for the Trump administration, and although a long-term state department official has spoken publicly about likely continuity rather than change (Balton, 2017), the US stand regarding oil and gas exploration in the Arctic was soon reversed. At the end of April President Trump issued an executive order that started the process of opening Alaska's Arctic waters for drilling (Martinson, 2017). Moreover, the tax reform decided by Congress in December 2017 included language that would lift an almost 40-year-old ban on prospecting for oil and natural gas in the Arctic National Wildlife Refuge, a move that has been described as an important step for reviving Alaska's oil industry (Nussbaum, 2017). The long-term repercussions from this and other similar actions are far from clear, but there is no mistaking the intent to undo Obama's climate mitigation legacy, including its Arctic components.
As the US chairmanship approached the Fairbanks ministerial, similar signs became apparent. The negotiations for a ministerial declaration were reportedly difficult as the United States initially wanted to delete language about a recent Arctic Council report that clearly showed the consequences of climate change in the Arctic, the so-called SWIPA report, which had received widespread media attention when it was released in early April (Rosen, 2017). In the end, the report was adopted but its dire messages did not make it through to the ministerial declaration text (Arctic Council, 2017b). The final text of the Fairbanks Ministerial Declaration was greeted by many with a sigh of relief; the Trump administration had not managed to change the Arctic Council's agenda. Moreover, at the Fairbanks meeting, Secretary of State Rex Tillerson confirmed US commitment to Arctic circumpolar cooperation (U.S. Department of State, 2017).

In conclusion, US Arctic politics since the late 1990s has been clearly shaped by global climate politics, with twists and turns depending on White House ambitions, where periods of active engagement and leadership have been punctuated by a stand based on climate skepticism. The reluctance has not been in relation to Arctic circumpolar cooperation but specifically directed at messages coming from climate science as knowledge and observations have been assessed by the Arctic Council. The policy mirrors a domestic tension field between environmental protection and a wish to capture economic opportunities related to Arctic resources. The situation can be described as the struggle between two competing frames: environment/environmental change on the one hand and economic development and competitiveness on the other. Aspects of all the other frames are also present but are secondary to these competing concerns.

\section{Discussion and conclusions}

Member states of the Arctic Council often start their public statements by asserting their status as an Arctic nation. The United States is no exception. However, this identity is a late development compared to, for example, Canada, Norway and Russia. Although the 1968 discovery of oil in Prudhoe Bay in Alaska led to an early push for a more coherent US policy approach towards the Arctic, a study of legislative actions from 1988 to 2002 concluded that no one has been marching on the Capitol Steps in Washington, DC to demand an Arctic policy (May et al., 2005). The authors of the study attributed the lack of policy coherence to a lack of clear constituency along with a diversity of components without major efforts to link them together. However, although not very visible in the myriad of legislative actions in the United States as a whole, the Arctic has been in focus for US political activities since the Alaska purchase in 1867 and rose during the Obama administration to a political priority with high-level engagement. The US was clearly taking a path towards becoming an Arctic nation. 
The review of US political priorities for the Arctic presented in this paper provides insight into what kind of Arctic actor the Unites States has been up until the end of the US chairmanship of the Arctic Council in May 2017, beyond the specific priorities of each administration. It has specifically identified the overarching logic within which policies and actions have developed during different time periods. The purpose has been to identify recurring frames as well as shifts in policy direction. The review shows that the most prominent recurring frame in US policy towards the Arctic over the past 150 years is economic development and competitiveness, and access to resources has provided the major political incentive. There are two exceptions. The first was during WWII and the early Cold War era, when the frame conflict and strategy dominated, and the second was during the Obama presidency, when environment/environmental change started to seriously compete with the economic development and competitiveness frame. The main reason appears to be a reassessment of the threats posed by climate change to core US national interests, a reassessment that was in turn linked to a move away from climate skepticism. One could argue that climate change as an issue became securitised (Buzan, Wæver, \& Wilde, 1998) and was no longer seen merely as an environmental concern or framed in terms of morality and ethics or social development/human wellbeing. Instead, it became framed as an issue that would affect everything related to the security concerns of the United States.

In some media and think-tank discussions about the Arctic, the conflict and strategy frame appears to have a much stronger foothold than in official US policy (based on a review of articles about the Arctic in the New York Times and Washington Post 2007-2015 and an assessment of Washington events about the Arctic featured in LinkTank). In the official policy rhetoric, the emphasis is instead on governing and politics in general, with a special focus on international cooperation. While the United States was resistant to international regional cooperation in the Arctic when it was first initiated in the 1990 s, the commitment to such cooperation in recent years appears to be solid even after the shift in presidency from Obama to Trump, despite their otherwise markedly different profiles and despite Trump's negative view of international cooperation in general. An essay written in 2013 by Ray Arnaudo - a long-term employee of the US State department - pointed to continuity over the previous two decades, with US priorities being national security, freedom of the seas, and international cooperation. In early policy statements the first two goals were closely related to conflict and strategy but have in recent discussions become more linked to the rule of law, such as adherence to the principles of the Law of the Sea, which was clearly articulated in the Ilulissat Declaration that was issued by the five Arctic rim states in 2008 (The Ilulissat Declaration, 2008). Arnaudo comments that "[t]he past two decades have witnessed an evolutionary trend and growth in United States perspective to welcome greater structured interna- tional and multilateral cooperation, which has resulted in more cohesion and better communication among Arctic countries" (Arnaudo, 2013).

A special issue in the US debate is the relationship to UNCLOS, because the declining sea ice has made questions about maritime rights and rights to marine resources politically more important than a few decades ago. The US did not sign UNCLOS when it was initially negotiated in 1982 and, even after resolving some issues of access to seabed resources beyond national jurisdiction in a special agreement in 1994, the US has yet to become party to the Convention because the necessary support from the Senate has been lacking. Nevertheless, the US view is that UNCLOS reflects customary international law and thus it follows its norms in practice. In the Arctic, this has become visible in the US signing of the 2008 Ilulissat Declaration. However, not being party to UNCLOS keeps the US from being able to submit claims to the Commission on the Limits of the Continental Shelf (for introduction to the US debate see https://www.unclosdebate.org). The trend towards a more positive attitude to international collaboration in the Arctic is also visible in the leading role that the United States has taken in negotiating an agreement among the five Arctic coastal states and the European Union on a moratorium of commercial fishery in the Central Arctic Ocean beyond national jurisdiction (the so-called Arctic donut hole) (Hoag, 2017).

The other major shift in US Arctic policy in the past two decades has related to attitudes towards climate change, Obama's stance being in stark contrast to that of his predecessor George W. Bush. With Trump, emphasis is again on climate denial and on creating opportunities for Alaska's oil and gas industry. Unless the political support for climate skepticism within the United States wanes in the face of increasing climate-related hardships and challenges, the see-saw of US climate policy in recent decades is likely to continue. Following the same political logic, policies towards oil exploitation in sensitive Arctic environments are likely to be in line with overall US policy towards hydrocarbon resources. It is probably no coincidence that policies that open new areas for exploitation have not come as a new Arctic policy but in documents relating to other policy fields (e.g. federal budget, Nussbaum, 2017; offshore energy policy, The White House President Donald Trump, 2017), where a frame focusing on economic development and competitiveness is the core political concern, in contrast to frames that focus on the environment/environmental change or on morality and ethics. Likewise, it is not a surprise that energy and drilling is the policy field in which the shift in administration from Obama to Trump has made the most obvious difference. So far, the major impact is domestic. In relation to Arctic international politics, the Trump administration has not yet questioned the international cooperation in the Arctic Council. It should be noted that participating in Arctic circumpolar cooperation is not necessarily at odds with developing Arctic hydrocarbon resources. Indeed, Trump's priorities 
are in line with some Arctic Council concerns, such as providing safe conditions for commercial activities in the Arctic. In other policy areas, it may be difficult to reach agreement on circumpolar cooperation and it would hardly be a surprise if official US climate skepticism under the Trump administration made it more difficult to agree on actions related to climate change mitigation or transformation towards a post-petroleum future.

A special issue for the development of US Arctic policy is the relationship between Washington and the state of Alaska. The United States can define itself as Arctic because of Alaska, but Arctic policies have nevertheless mainly been decided by national foreign priorities. Alaska has often pushed Washington to pay attention to the Arctic, for example in the work towards the Arctic Research and Policy Act of 1984, and during the Obama presidency, Alaska's own priorities came more to the fore. An example is that the Arctic Executive Steering Committee had an explicit task of "improving the coherence of engagement with the State of Alaska and Alaska Native communities and supporting the U.S. Chairmanship of the 8-nation Arctic Council for 2015-2017" (The White House President Barack Obama, 2015b).

Alaska also has its own Alaska Arctic Policy Commission (AAPC), created in 2013 with the aim of producing "a policy for Alaska's Arctic that reflects the values of Alaskans, provides a suite of options to capitalize on the opportunities and safeguard against risk" (Alaska Arctic Policy Commission, n.d.). It launched its final report in January 2015 (Alaska Arctic Policy Commission, 2015). Its activities illustrate an increasing engagement by subnational government in Arctic policy, with an eye towards the local and regional implications of climate change.

While national and state priorities for the Arctic sometimes go hand in hand, there are also areas of clear conflict. In the case of Alaska, a major contention relates to oil and gas exploration versus environmental interests. When Obama announced his ban on further exploration in the Arctic Ocean, it was met by protest from Alaskan senators, while the Trump order to open for further exploration was met with applause. Such conflicts illustrate one of the key areas of opposing interests in the US Arctic that are also visible in national policy development and have been so in various iterations ever since the discovery of oil at Prudhoe Bay in 1968. This tension is likely to remain and to require balancing between different interests in the future, at least for as long as fossil fuels are important for national energy security and for the economy of Alaska. The United States is not alone among the Arctic states in its dependency on hydrocarbon resources. However, the United States has been the major actor trying to actively play down the climate-related work in the Arctic Council during presidencies when information from climate science did not fit well with policy priorities.

In conclusion, and returning to the overarching question of continuity or change in US Arctic policy, there has been continuity ever since the United States became an Arctic nation in emphasising the use of Arctic resources to support US economic development and competitiveness. At times this emphasis has been circumscribed by environmental concerns, and during the Obama presidency a focus on the impacts of climate change became prominent to the point that they were framed as a security issue relating to everything, not just the environment. Given recent developments under President Trump, Obama's emphasis on climate change and the accompanying effort to halt offshore oil development could be described as a short-lived discontinuity. However, given that the balance between concerns for climate change and the economic importance of fossil-fuel extraction is a recurring political controversy, and specific policies depend on who is in power, it is too early to make a judgement on what is a temporary shift specific to Trump's presidency or a new long-term trend. What can be described as a significant shift over time and the establishment of a new continuity, becoming apparent in the 1990s, is a move from reluctance to support of circumpolar international cooperation.

\section{Acknowledgements}

I greatly appreciate the time and help from several US civil servants who provided useful background context for the document analysis. I also want to express my gratitude for the hospitality of the German Marshall Fund of the United States during my Mistra Arctic Fellowship.

\section{Financial support}

This work was supported by MISTRA - The Swedish Foundation for Strategic Environmental Research, and the Swedish Research Council Formas (Grant 2011-20141020).

\section{References}

Alaska Arctic Policy Commission. (2015). Final report of the Alaska Arctic Policy Commission. Alaska Arctic Policy Commission.

Alaska Arctic Policy Commission. (n.d.). Alaska Arctic Policy Commission. Retrieved June 27, 2017, from http://www. akarctic.com/about-the-commission/

Archer, C., \& Scrivener, D. (2000). International co-operation in the Arctic environment. In M. Nuttall \& T.V. Callaghan (Eds.), The Arctic: environment, people, policy (pp. 601-619). Amsterdam: Harwood Academic Publishers.

Arctic Council. (2017a). Agreement on enhancing international Arctic scientific cooperation. Retrieved from https://oaarchive. arctic-council.org/handle/11374/1916

Arctic Council. (2017b). Fairbanks Declaration 2017: on the occasion of the tenth ministerial meeting of the Arctic Council. Retrieved from https://www.state.gov/e/oes/rls/ other/2017/270802.htm

Arnaudo, R. V. (2013). United States policy in the Arctic. In P. A. Berkman \& A. N. Vylegzhanin (Eds.), Environmental security in the Arctic Ocean (pp. 81-91). Dordrecht: Springer Netherlands. doi: 10.1007/978-94-007-4713-5_9 
Balton, D. (2017). David Balton speech at Arctic Frontiers, Tromsø Norway 25 January 2017. Arctic Frontiers. Retrieved from https://www.youtube.com/watch?v=AWx2yzWm77Y

Barnett, J. K. (2013). Alaskan history - in brief. Anchorage, AL: Todd Communications.

Bird, K. J., Charpentier, R. R., Gautier, D. L., Houseknecht, D. W., Klett, T. R., Pitman, J. K., ... Wandrey, C. J. (2008). Circum-Arctic resource appraisal: estimates of undiscovered oil and gas north of the Arctic circle. US Geological Survey fact sheet 2008-3049. U.S. Geological Survey. Retrieved from http://pubs.usgs.gov/fs/2008/3049/fs2008-3049.pdf

Björnehed, E., \& Erikson, J. (2018). Making the most of the frame: developing the analytical potential of frame analysis. Policy Studies, 39(2), 109-126. doi: 10.1080/01442872.2018.1434874

Bloom, E. (1999). Establishment of the Arctic Council. Retrieved June 23, 2016, from http://www.state.gov/e/oes/ocns/opa/ arc/ac/establishmentarcticcouncil/index.htm.

Borgerson, S. G. (2008). Arctic meltdown. Foreign Affairs, March/April 2008

Buurman, T., \& Christensen, M. (2017). Governance and the changing Arctic: news framings in U.S. newspapers from 2007 to 2015. Presented at the Conference on Communication and Environment (COCE), Leicester, 28 June-3 July, Leicester, UK.

Buzan, B., Wæver, O., \& Wilde, J. D. (1998). Security: A new framework for analysis. Boulder, CO: Lynne Rienner Publishers.

Canada-United States: Agreement on Arctic cooperation and exchange of notes concerning transit of Northwest Passage. (1989). International Legal Materials, 28(1), 141-145.

Christensen, M. (2013). Arctic climate change and the media: The news story that was. In M. Christensen, A. E. Nilsson, \& N. Wormbs (Eds.), Media and the politics of Arctic climate change. When the ice breaks (pp. 26-51). New York, NY: Palgrave Macmillan.

Christensen, M., Nilsson, A. E., \& Wormbs, N. (Eds.). (2013). Media and the politics of Arctic climate change. When the ice breaks. New York, NY: Palgrave Macmillan.

Cohen, A. (2010, June 15). From Russian competition to natural resources access: Recasting U.S. Arctic policy. Washington DC: Heritage Foundation. Retrieved June 26, 2017, from /europe/report/russian-competitionnatural-resources-access-recasting-us-arctic-policy

Cole, T., \& Cravez, P. (2004). Blinded by riches: The permanent funding problem and the Prudhoe Bay effect (No. UA Research Summary No. 3). Anchorage, AL: Institute of Social and Economic Research, University of Alaska Anchorage.

Conley, H. (2013). The new foreign policy frontier. U.S. interests and actors in the Arctic. Washington D.C.: Center for Strategic and International Studies (CSIS). Retrieved from https: //www.csis.org/analysis/new-foreign-policy-frontier

Cornell, S., Downing, A., \& Clark, D. (2016). Multiple Arctics: Resilience in a region of diversity and dynamism. In M. Carson \& G. Peterson (Eds.), Arctic resilience report (pp. 27-61). Stockholm: Stockholm Environment Institute and Stockholm Resilience Centre.

Doel, R. E. (2003). Constituting the postwar earth sciences: The military's influence on the environmental sciences in the USA after 1945. Social Studies of Science, 33(5), 635-666.

Emmerson, C. (2010). The future history of the Arctic. London: Bodley Head.

Ervin, A. M. (1976). The emergence of native Alaskan political capacity, 1959-1971. Musk Ox Journal, 19. Retrieved from http://www.alaskool.org/projects/ancsa/ARTICLES/ ervin1976/Ervin MuskOx.htm
Friedheim, R. L. (1986). The U.S.-Canada Arctic Policy Forum: Impressions from the American Co-Chair. ARCTIC, 39(4), 360-367.

Heymann, M., Knudsen, H., Lolck, M. L., Nielsen, K. H., \& Ries, C. J. (2017). Exploring Greenland: science and technology in Cold War settings. Scientia Canadensis: Canadian Journal of the History of Science, Technology and Medicine, 33(2), $11-42$.

Hickok, D. M., Weller, G., Davis, T. N., Alexander, V., \& Elsner, R. (1983). United States Arctic Science Policy. Alaska Council of Science and Technology.

Hoag, H. (2017). Nations agree to ban fishing in Arctic Ocean for at least 16 years. Science. https://doi.org/doi:10.1126/ science.aar6437

Huebert, R. (2009). United States Arctic policy: The reluctant Arctic power. University of Calgary. School of Public Policy. Retrieved from http://www.policyschool.ca/publications/ united-states-arctic-policy-reluctant-arctic-power/

Kankaanpää, P., \& Young, O. R. (2012). The effectiveness of the Arctic Council. Polar Research, 31(0), 17176. doi: 10.3402/polar.v31i0.17176

Keskitalo, E. C. H. (2004). Negotiating the Arctic: The construction of an international region (1st ed.). London: Routledge.

Martinson, E. (2016a, June 10). Now trending in DC: Arctic issues. Alaska Dispatch News. Retrieved August 10, 2016, from http://adn-pb. internal.arc2.nile.works/pb/arctic/2016/06/10/now-trendingin-dc-arctic-issues/

Martinson, E. (2016b, December 20). Obama prohibits drilling in most US Arctic waters. Alaska Dispatch News. Retrieved from https://www.adn.com/politics/2016/12/20/obamaprohibits-offshore-drilling-in-most-of-us-arctic-waters/

Martinson, E. (2017, April 28). Trump pushes to expand offshore drilling in the Arctic. Alaska Dispatch News. Retrieved from https://www.adn.com/politics/2017/04/28/ trump-reversing-obama-pushes-to-expand-drilling-in-arcticwaters/

May, P. J., Jones, B. D., Beem, B. E., Neff-Sharum, E. A., \& Poague, M. K. (2005). Policy coherence and componentdriven policymaking: Arctic policy in Canada and the United States. Policy Studies Journal, 33(1), 37-63. doi: 10.1111/j.1541-0072.2005.00091.x

Myers, S. L. (2011, May 12). 8 Arctic nations pledge cooperation. The New York Times. Retrieved from https://www.nytimes. com/2011/05/13/world/europe/13arctic.html

National Security Presidential Directive-66 on Arctic Region Policy (2009). Retrieved from https://fas.org/irp/offdocs/nspd/ nspd-66.htm

Nilsson, A. E. (2007). A changing Arctic climate. Science and policy in the Arctic Climate Impact Assessment. Department of Water and Environmental Studies, Linköping University, Sweden.

Nilsson, A. E. (2012). The Arctic environment - from low to high politics. In Arctic Yearbook 2012. Akureyri: Northern Research Forum. Retrieved from http://www.arcticyearbook. com/images/Articles_2012/Nilsson.pdf

Nilsson, A. E., \& Koivurova, T. (2016). Transformational change and regime shifts in the circumpolar Arctic. Arctic Review on Law and Politics, 7(2), 179-195. doi: $10.17585 /$ arctic.v7.532

Nisbet, M. C. (2009). Communicating climate change: Why frames matter for public engagement. Environment: Science and Policy for Sustainable Development, 51(2), 12-23. doi: 10.3200/ENVT.51.2.12-23

Nord, D. C. (2007). Searching for the North in North American foreign policies: Canada and the United States. Amer- 
ican Review of Canadian Studies, 37(2), 207-217. doi: 10.1080/02722010709481855

Nussbaum, A. (2017, December 20). Arctic refuge just the start of Trump's move to unlock Alaska oil. Bloomberg.com. Retrieved from https://www.bloomberg.com/ news/articles/2017-12-20/arctic-refuge-just-the-start-astrump-moves-to-unlock-alaska-oil

Østhagen, A. (2011, December 12). The United States as an Arctic actor. The Arctic Institute. Center for Circumpolar Security Studies. Retrieved August 10, 2016, from http:// www.thearcticinstitute.org/united-states-as-arctic-actor/

Pincus, R., \& Ali, S. H. (2016). Have you been to 'The Arctic'? Frame theory and the role of media coverage in shaping Arctic discourse. Polar Geography, 39(2), 83-97. doi: 10.1080/1088937X.2016.1184722

Rogne, O., Rachold, V., Hacquebord, L., \& Corell, R. (Eds.). (2015). IASC 25 years. Retrieved from https://view.joomag. com/iasc-25-years/0102946001421148178

Rosen, Y. (2017, May 30). Trump administration sought lastminute changes to soften Arctic Council climate-change commitment. Arctic Now. Retrieved June 20, 2017, from http://www.arcticnow.com/pb/politics-policy/2017/05/30/ trump-administration-sought-last-minute-changes-tosoften-arctic-council-climate-change-commitment/

Seward, W. H. (1869). Alaska, speech of William H. Seward at Sitka, August 12, 1869 [microform]. Washington: Philip \& Solomons. Retrieved from http://archive.org/details/cihm_ 16134

Shadian, J. M. (2014). The politics of Arctic sovereignty. Oil, ice and Inuit governance. London and New York: Routledge.

Stachowiak, S. (2013). Pathways for change. 6 theories of how policy change happens. Organizational Research Services. Retrieved from https://cdn2.hubspot.net/hubfs/ 316071/Resources/Article/Pathways\%20for\%20change\% 206\%20theories\%20about\%20how\%20policy\%20change\% 20happens.pdf

Storholm, L. (2017, February 1). Does not think the USA will change its Arctic policy. High North News. Retrieved June 26, 2017, from http://www.highnorthnews.com/ does-not-think-the-usa-will-change-its-arctic-policy/

Tennberg, M. (1998). Arctic environmental cooperation: A study in governmentality. Farnham: Ashgate Publishing Company.

The Ilulissat Declaration. (2008). (Declaration). Ilulissat, Greenland. Retrieved from oceanlaw.org

The White House President Barack Obama. (2015a, January 21). Executive Order - Enhancing Coordination of National Efforts in the Arctic. Retrieved June 26, 2017, from https://obamawhitehouse.archives.gov/the-press-office/ 2015/01/21/executive-order-enhancing-coordinationnational-efforts-arctic

The White House President Barack Obama. (2015b, August 13). Ambassador Mark Brzezinski Appointed Executive Director of the Arctic Executive Steering Committee. Retrieved June 27, 2017, from https://obamawhitehouse. archives.gov/blog/2015/08/13/ambassador-markbrzezinski-appointed-executive-officer-arctic-executive-steering
The White House President Barack Obama. (2016, December 9). Executive Order - Northern Bering Sea Climate Resilience. Retrieved June 26, 2017, from https://obamawhitehouse.archives.gov/the-press-office/ 2016/12/09/executive-order-northern-bering-sea-climateresilience

The White House President Donald Trump. (2017, May 3). Implementing an America-First Offshore Energy Strategy. Executive Order 13795. Retrieved from https://www. federalregister.gov/documents/2017/05/03/2017-09087/ implementing-an-america-first-offshore-energy-strategy

United States. (1983). National Security Decision Directive (1983) U.S. Arctic Policy. Retrieved from http://www.fas.org/ irp/offdocs/nsdd/nsdd-090.htm.

United States. Arctic Research and Policy Act of 1984 (amended 1990), Pub. L. No. PUBLIC LAW 98-373-July 31, 1984; amended as PUBLIC LAW 101-609-November 16, 1990 (1984). Retrieved from http://www.nsf.gov/geo/plr/ arctic/iarpc/arc_res_pol_act.jsp

United States. (1994). United States Policy on the Arctic and Antarctic region. Presidential decision directive NSC-26, June 9 , 1994. Retrieved from https://fas.org/irp/offdocs/pdd/pdd-26. pdf

United States and Canada. (2016, March 10). U.S.Canada Joint Statement on Climate, Energy, and Arctic Leadership. Retrieved June 26, 2017, from http://pm.gc.ca/ eng/news/2016/03/10/us-canada-joint-statement-climateenergy-and-arctic-leadership

United States Arctic policy group. (1971). National Security Decision Memorandum 144. Retrieved from http://www.fas. org/irp/offdocs/nsdm-nixon/nsdm-144.pdf

United States Department of Defense. (2013, November). Arctic Strategy.

United States Federal Government. (2013, May 10). The National Strategy for the Arctic Region. Retrieved from https://obamawhitehouse.archives.gov/blog/2013/05/10/ national-strategy-arctic-region-announced

U.S. Department of State. (2017). Remarks by the U.S. Secretary of State at the Fairbanks Ministerial meeting. Retrieved from https://oaarchive.arctic-council.org/handle/11374/2017

U.S. Senate Committee on Commerce, Science, \& Transport. (2004, March 3). Climate Change. Retrieved from https:// www.commerce.senate.gov/public/index.cfm/2004/3/

van Hulst, M., \& Yanow, D. (2016). From policy "frames" to "framing": Theorizing a more dynamic, political approach. The American Review of Public Administration, 46(1), 92112. doi: $10.1177 / 0275074014533142$

Wilson Rowe, E. (2013). A dangerous space? Unpacking state and media discourses on the Arctic. Polar Geography, 36(3), 232-244. doi: 10.1080/1088937X.2012.724461

Young, O. R. (1985). The age of the Arctic. Foreign Policy, 61, 160-179.

Young, O. R. (1998). Creating regimes: Arctic accords and international governance. Ithaca, NY: Cornell University Press.

Young, O. R., \& Einarsson, N. (2004). Introduction. In Arctic Human Development Report (pp. 15-26). Akureyri, Iceland: Stefansson Arctic Institute. 